\title{
A Matter of Age: Negotiation for Meaning in Child and Adult Interactions
}

\author{
Raúl Azpilicueta-Martínez \\ Department of Human Sciences and Education \\ Public University of Navarra (UPNA-NUP) \\ raul.azpilicueta@unavarra.es \\ Amparo Lázaro-Ibarrola \\ Department of Human Sciences and Education \\ Public University of Navarra (UPNA-NUP) \\ amparo.lazaro@unavarra.es
}

\begin{abstract}
Findings from task-supported interaction with adult populations have often been transferred to children with little to no modification. When (considerable) differences have been identified, adult and children interactions were analysed while performing different tasks or at different proficiency levels. This article attempts to provide a more reliable comparison by analysing level-matched adults and children performing the exact same task. This study examines the negotiation for meaning (NoM) strategies and their communicative functions in 20 young (age 8-9) children and 14 adults performing an information-gap narrative task with an adult proficient speaker. All participants had Spanish as their L1 and were beginner learners of English as a foreign language (EFL). The results revealed that the adult group produced significantly higher rates in all NoM strategies, with the exception of comprehension checks. However, both populations displayed commonalities in their interactional patterns, with a similar proportional use and functions of the NoM strategies and a clear tendency to imitate elements of their more proficient interlocutor's output via other-repetitions. These findings provide evidence that the age factor at this level of proficiency may have a greater impact on the amount of NoM generated than on the type and function of the NoM strategies used.
\end{abstract}

Keywords: Interaction; negotiation for meaning; children; adults; EFL.

\section{Resumen}

Los hallazgos en estudios de interacción con poblaciones adultas han sido extrapolados a menudo a la población infantil sin apenas modificaciones. Además, 
las diferencias encontradas entre niños y adultos provienen de estudios en los que estas poblaciones realizan diferentes tareas o tienen diferentes niveles de competencia lingüística. Este trabajo de investigación pretende ofrecer una comparación más fiable mediante el análisis de interacciones de adultos y niños con el mismo nivel de competencia y realizando la misma tarea. Así, nuestro estudio analiza las estrategias de negociación de significado (NdS) y sus funciones comunicativas en las narraciones de una historia con vacíos de información de 20 aprendices jóvenes (8-9 años) y 14 adultos con un adulto experto. Los participantes compartían el castellano como L1 y tenían un nivel básico en inglés como lengua extranjera. Los resultados muestran que el grupo adulto utilizó más estrategias de NdS, a excepción de las comprobaciones de comprensión. Sin embargo, ambas poblaciones mostraron una proporción similar en el uso y funciones de dichas estrategias y una clara tendencia a imitar elementos de la producción de su interlocutor, más competente lingüísticamente, mediante el uso de repeticiones. Estos hallazgos sugieren que, con bajos niveles de competencia lingüística, el impacto del factor edad puede estar más relacionado con la cantidad de $\mathrm{NdS}$ que con el tipo y funciones de sus estrategias.

Palabras clave: Interacción; negociación de significado; niños; adultos; ILE.

\section{Introduction}

As on frequent occassions in the field of SLA, interaction-based research started with adults (Long, 1983a; Mackey, 1999; Shehadeh, 1999; Varonis \& Gass, 1985) and only subsequently did it address children as an object of study (Butler \& Zeng, 2014; Mackey \& Oliver, 2002; Oliver, 2009). This originally led to the default transfer of general assumptions to the latter population with little or no empirical evidence despite both groups' notable differences (Birdsong, 2005; García Mayo, 2018; García Mayo \& García Lecumberri, 2003; Muñoz \& Singleton, 2011; Singleton \& Ryan, 2004). Coinciding in time with the expansion of foreign language (FL) programmes and content and language integrated learning (CLIL) (Dalton-Puffer, 2011; Sylvén, 2013), a growing body of research warned about the lack of solidity of such transfer, (Mackey \& Gass, 2005, following Thompson \& Jackson, 1998; Paradis, 2007) and gradually contributed to shed light on the distinct features of children, overlooked in interaction-based research until the late nineties (e.g. Oliver, 1998; Van den Branden, 1997).

Breakthrough studies at the turn of the century outlined the peculiarities in the interactional patterns of children learning English as a second language (ESL) (e.g., Oliver, 1998, 2000, 2002; Oliver \& Mackey, 2003; Mackey, Kanganas, et al., 2007) and acted as a catalyst for subsequent research on EFL young learners (YLs) 
(Azkarai \& García Mayo, 2015; García Mayo \& Hidalgo, 2017). Findings in both contexts demonstrated the benefits of NoM for children when interacting with adults and also with peers and allowed researchers to champion the use of interactive tasks as a valuable pedagogical practice with ESL/EFL YLs (Hidalgo, 2019; García Mayo \& Imaz Agirre, 2019). However, while children were shown to be able to negotiate for meaning, all studies consistently reported greater amounts of negotiation among adults in aspects such as NoM strategies (e.g., Oliver, 1998, 2000, 2002), reception of negative feedback (Oliver, 2000) provision of feedback and modified output (Oliver, 2000; Mackey, Oliver, et al., 2003), or the use of task-related strategies, although results in aspects such as L1 use seem far less conclusive (Pinter, 2006). However, these claims have been made on the basis of empirical studies carried out either with children or with adults, which implies that the data from each age group were elicited under different conditions.

In fact, very few studies to date have included EFL adult and children populations within the same study and/or performing the same interactive tasks (Pinter, 2006; Azpilicueta-Martínez, 2020). Pinter's (2006) study examined the task solving strategies in both populations, and the results in her analysis provided evidence that adults were more efficient than children in the way they handled the tasks. On the other hand, a study by Lázaro-Ibarrola and Azpilicueta-Martínez (2019b) compared the NoM in child-child and adult-adult interactions and identified important similarities between both age groups as regards both the amount of NoM strategies as well as the functions they served, questioning previous research claims.

Therefore, the few studies comparing adults and children have done so with participants interacting with age-matched peers (i.e., child-child vs. adult-adult). What is more, if we focus specifically on interaction-based studies where children and adults negotiate with an expert speaker of the language (i.e., child-expert vs. adult-expert), research comparing both populations within the same study is simply non-existent. However, it is also known that learner-teacher interaction constitutes a frequent real classroom situation (Tuan \& Nhu, 2010), and that it mirrors the most widespread format of oral examinations at the lower levels of the Common European Framework of Reference for Languages (CEFR), facts which highlight the need of more studies analysing interactional patterns in this particular setting even more.

In sum, research comparing children and adult interactions is in dire need of more studies. Specifically, more light needs to be shed on the ways these populations interact with expert speakers of the target language (TL). The present study attempts to address this research niche by specifically analysing the conversational patterns of EFL children and adult beginners at the same level of proficiency while interacting with a proficient speaker of English in an information-gap narrative oral task. 


\section{Literature review}

\subsection{The patterns of interaction in EFL children and adults}

Interaction-based studies (Long \& Porter, 1985; Philp \& Tognini, 2009) put forward the benefits of conversational interaction for SLA, since NoM "facilitates language acquisition because it connects input (what learners hear and read); internal learner capacities, particularly selective attention; and output (what learners produce) in productive ways" (Long, 1996: 451-452). The first studies within the interactionist framework operationalised NoM by means of strategies, comprising conversational adjustments (CAs) and different forms of repetition. With the increase of studies on the subject, this canonical inventory has been augmented by additional strategies, namely 'acknowledgements' and supplemented by the inclusion of the communicative functions these strategies serve (see 3.5. Data coding and analysis). A common conclusion arising from these studies is that learners of English as an L2 are able to negotiate for meaning, use the wide range of strategies described above, and overcome communication breakdowns successfully (García Mayo \& Imaz Agirre, 2019; Hidalgo, 2019). Also, NoM proved to be affected, among other factors, by the inter-related effects of the proficiciency level of the conversational partners (learner/expert) and the age of the interlocutors (i.e., adults vs. children) (e.g., Mackey \& Oliver, 2002).

One of the most consistent findings when comparing conversational patterns in adult and children learners was the relatively higher overall use of strategies of the former (Long, 1983a; Oliver, 1998, 2002, to name but some). However, values for several NoM strategies in dyads made up of native-native (NS-NS) and non-nativenative (NNS-NS) children (clarification requests and confirmation checks, respectively, and repetitions in both cases) were higher than those in adult NS-NS dyads (Long, 1983a; Oliver, 1998). This finding was hypothesised to be related to the effect of the 'nativeness or nonnativeness' of the interlocutor in relation to the age of the learners (Oliver, 1998: 377). In other words, the proficiency of a conversational partner affected children and adults in different ways. With the exception of the values for otherrepetition, whenever one of the subjects in the adult pairings was a learner (NNS), values in all NoM strategies were substantially higher than those of YLs (Long, 1983a; Oliver, 1998).

In addition to the greater quantity of strategies reported in adult populations, recurrent differences have also been reported when looking at the proportional use of certain types of negotiations. For example, although mean values are still lower for YLs, children have proven to make a wider proportional use of 'self' NoM strategies, and to be barely interested in their partners' understanding if compared with adult 
populations (Oliver, 1998, 2009). This feature has been attributed to the egocentricity inherent to YLs, and seems to intensify in the case of younger children, as underpinned by more recent work comparing YLs of different ages (García Mayo \& Lázaro-Ibarrola, 2015; Azkarai \& Imaz Agirre, 2016; Hidalgo, 2019).

However, as Oliver (1998) acknowledges, some of the aforementioned studies make claims about the differences in NoM between adult and children without having been able to carry out a statistical comparison, given the use of dissimilar methods in data collection, the use of substantially different task types or even number of tasks (e.g., comparison of NoM rates between Long, 1983a, and Oliver, 1998), and the different proficiency levels, age and learning contexts of the interlocutors. Recently, findings in one study specifically comparing EFL children and adult populations in peer interaction while performing the same task under the same conditions did not fully support the assumption that adults negotiate more and that children are not so aware of their interlocutor's needs (Lázaro-Ibarrola \& Azpilicueta-Martínez, 2019b). Rather on the contrary, results revealed statistically significant higher rates in child-child interactions on the overall number of CAs as well as in self-repetition, and similarities were reported regarding the type and degree of use of the communicative functions NoM strategies served.

When looking at the proficiency level of the interlocutors researchers have found that, provided a minimum threshold level of proficiency has been attained (LázaroIbarrola \& Azpilicueta-Martínez, 2015), the mastery of the TL is inversely proportional to the amount of NoM generated in dyadic interaction. At one end nonnative dyads produced the most NoM, as opposed to native speaker pairings, as the following scale illustrates $(\mathrm{H}=$ high; $\mathrm{L}=\mathrm{low} ; \mathrm{VL}=$ very low; $\mathrm{NS}=$ native speaker; $\mathrm{NNS}=$ non-native speaker):

\section{L-L $>$ H-L $>$ H-H $>$ L-NS $>$ H-NS $>$ NS-NS $>$ VL-VL}

(Lázaro-Ibarrola \& Azpilicueta-Martínez, 2015, adapted from Oliver, 2002)

These findings have been explained by the scarcity of communication breakdowns generated by more proficient learners (Azkarai \& Imaz Agirre, 2016; Ellis, 1985; Gass \& Varonis, 1985). However, again these rates belong to different studies using different tasks, categories (acknowledgements) and contexts (ESL vs. EFL), and, as mentioned above, the proficiency of the conversational partners appears to affect each age group differently. Recent work by Lázaro-Ibarrola and Azpilicueta-Martínez (2019a) compared the conversational patterns of child-child (L-L) and child-expert (L-near native) interactions. Contrary to the classification above, values for nearly all NoM strategies (except other-repetitions and acknowledgements, the latter being nearly 
identical) were higher in the child-child pairings, including statistically significant differences for comprehension checks and self-repetitions.

In sum, both the age (child vs. adult) and the proficiency of the conversational partner (learner-learner or learner-expert/teacher), have proven to affect the patterns of interaction (Hidalgo, 2019; Oliver, 2000). While some research has been conducted comparing children and adults when interacting with peers and has served to challenge and qualify previous findings, to date no study has compared children and adults when interacting with an expert of the TL, under similar conditions and within the same study, thus making a call for more research to further understand the different interactional patterns of each age group.

\section{Method}

\subsection{Research questions}

This study examines the role that age plays in the patterns of interaction of EFL children and adults, at an A1 level of proficiency, interacting with a proficient speaker of the TL (teacher) while performing the same task. Our research questions are the following:

1. What are the patterns of interaction of level-matched EFL children and adults performing the same oral task with a proficient speaker of the TL?

2. How do results in this study compare with previous research?

\subsection{Participants}

The present study examines the patterns of interaction of twenty (20) EFL children and fourteen (14) EFL adults at an A1 level of the CEFR while performing two narrative tasks with a proficient speaker of the TL. The children group included eleven (11) girls and nine (9) boys, with a mean age of 8.5. All children participants were enrolled in Year 3 at a primary state school in a village in northern Spain. At the time of data collection they had been provided with nine (9) weekly EFL 50-minute lessons for six (6) school years, comprising, in turn, five (5) EFL sessions, plus four (4) sessions of subjects taught through the medium of English (CLIL). Prior to the study the children were told that they were going to take part in an English-speaking game, which did not imply any form of test or examination. All parents were duly informed that their children's performances would be used for research purposes exclusively 
and would remain anonymous. Due permission was granted by both parents and the school itself.

All 14 adult subjects in this study had enrolled in two A1 courses at two EFL schools for adult learners. The contents and material in those courses met the criteria established by the Common European Framework of Reference for Languages (CEFR) for an A1 level. Their age ranged from 31 to 69 , with a mean age of 47. Due permission was granted by all subjects.

The implementation of an oral proficiency placement test with participants was not deemed appropriate for several reasons. For one thing, defining proficiency, a controversial source of debate itself (Pienemann \& Johnston, 1987), seems to further complicate when comparing two distinct age groups (Oliver, 2000), as is the case with this study. In addition, familiarity with a given task in EFL has been reported to impinge on a learner's output (Kazemi \& Zarei, 2015; Qiu, 2019). Consequently, the proficiency levels of participants were based on a) the children's internal (school) and external (regional Government) assessment and b) the adults' enrolment in the A1 group. The children's internal school assessment was provided by the school teachers and was based on their regular evaluation of the students' performance. The external assessment consisted of a test developed and administered by the Government to all students in the region of Navarra at the end of the 2nd year of primary. As for the adults, no level test was administered, their A1 level was guaranteed by their enrolment in the EFL A1 courses in their schools where students have to demonstrate their level (by means of a test or an official certificate) to be allowed to enrol. Also, at the beginning of each academic year, those students whose language level is deemed higher are encouraged to move up to the A2 level.

The researcher interacting with the subjects was one of the authors in the present study. Although not a NS, his proficiency level was certified by the obtention of the Cambridge Proficiency in English (CPE) exam (level C2 of the CEFR) with a top score in the oral production skill. The researcher did not know the students prior to the study.

\subsection{The task}

The task consisted of two (2) stories which featured an identical layout, although based on different stories (see Appendices A and B for stories one and two, respectively). In each of them, one participant (a) was provided with a poster story comprising five (5) pictures showing a sequence of numbered events which s/he had to narrate in that specific order. The other participant (b), the 'story-builder' was given a blank poster, 
plus eight (8) scattered pictures including the five pictures given to participant (a) plus three (3) additional distractors. In order to favour negotiations, the order in the story provided to participant (a) was not fully predictable, and its distractors were carefully planned with the aim of forcing participants to negotiate for meaning.

The adequacy to generate interaction of the tasks with both populations was piloted before the study, yet participants involved in the piloting were excluded from the final pool of subjects.

\subsection{Procedure}

Data were collected as follows. On the first story, the researcher narrated the story so that the participants had to arrange the sequence of events correctly and leave the three wrong pictures out. The researcher narrated the story using exactly the same script (see Appendix C), and provided the exact same feedback to all participants depending on their responses. The script included a few warm-up questions, not coded in the study, in order for the learners to get acquainted with the expert speaker and feel more comfortable. An opaque screen was placed between participants in order to maximise verbal communication. The researcher took on the narrator role (a) first with the aim of familiarising the students with the task and and to dispel any feelings of unease before asking them to take on the narrator role. When the participant felt that $\mathrm{s} /$ he had finished with the task, the researcher would stand up and double-check the participant's poster. If the pictures were not placed in the same order as (a) he would then point out which picture(s) were wrong, without providing any further information, until the story was solved successfully.

Once the first story was finished the researcher and the subjects swapped roles and interacted again in order to co-construct the second story, that is, the participant, who had acted as the story-builder, would now take on the narrator role, and the researcher, who had the narrator role during the first story, would now become the story-builder. All interactions were filmed and voice-recorded using an integrated webcam and a voice recorder.

\subsection{Data coding and analysis}

The participants' interactions were directly observed and video-recorded by one of the researchers. Their conversations were then transcribed verbatim, and coded following the NoM categorisation commonly used in interaction-based research (Long, 1983a, 1983b; Oliver, 1998; Pica, 1987), which comprises CAs and repetitions. CAs include, in turn, clarification requests, confirmation checks and comprehension 
checks, with the addition of 'acknowledgements' as pointed out in more recent studies (Ducasse, 2010; Galaczi, 2013). Repetitions include instances of self-repetition and other-repetition. We will now describe these elements succinctly and provide examples from the current study.

Clarification requests are used by the listener when they need to make clear what their interlocutor has said (Oliver, 2002: 103). In example 1 below, the child is describing the last image in story 2 (see Appendix B) to the researcher, in which the difference between the right picture and the distractor hinges on the length of the snowman's arms. When the researcher asks about that element the child seems to fail to understand the question and resorts to a clarification request (turn 3), which then triggers a modification in the researcher's wording of the same question (turn 4), and ultimately leads to an understanding of the query and subsequent (successful) response (turn 5):

\section{Example 1 (Child-researcher)}

1. Child: The story finish that the children put the, the hat, the nose and the scarf to the snowman and they are, they are happy.

2. Researcher: Ok. Are the snowman's arms long or short now?

3. Child: What? [Clarification request]

4. Researcher: The snowman's arms: are they long or short?

5. Child: Long.

Confirmation checks are used by the listener when they need to ratify that they have really understood what their interlocutor has said (Oliver, 2002: 103). This is illustrated in example 2 (below; story 2), in which the adult participant requests confirmation (turn 9) of an utterance in which the researcher was co-constructing the story (turns 6 and 8), triggering a confirming response (turn 10), and requesting confirmation again (turn 11). In this case, such persistence appears to be related to the participant failing to see the pictures correctly, suggested by the successful response once she puts her glasses on (turn 15):

\section{Example 2 (Adult-researcher)}

1. Adult: Erm... erm... a... y... there is a... a... a man?

2. Researcher: Yes.

3. Adult: Sit in the... no sé cómo se dice 'banco' (I don't know how to say 'banco' 'bench'). 
4. Researcher: He's sitting on a bench.

5. Adult: On a bench.

6. Researcher: Very good, eating a banana.

7. Adult: Eh?

8. Researcher: The man is sitting holding a banana.

9. Adult: A banana?

[Confirmation check]

10. Researcher: Yes.

11. Adult: Banana? [Confirmation check]

12. Researcher: Yeah....

13. Adult: Banana... The bank.

14. Researcher: Yes.

15. Adult: Ah!!! Vale, espera ('Ok, hang on') (Adult puts on glasses). Yes! Eating a banana, yes, yes, yes.

Comprehension checks are performed by the speaker - as opposed to the previous two CAs - to ensure that the preceding utterance has been fully understood by the listener (Oliver, 2002):

Example 3 (Adult-researcher)

1. Adult: The, the girl and the, and the boy make, make the ball.

2. Researcher: But, who is making the bigger ball: the girl or the boy?

3. Adult: The girl, the girl.

4. Researcher: The girl, yes? Ok, thank you.

5. Adult: Erm... Number three? [Comprehension check]

6. Researcher: Yes.

7. Adult: They make a... a.... (pause) d... erm... doll? Doll... snow...dolls? They... make two... two... two, two, two eyes, and a.... erm... Es que no sé cómo se dice 'muñeco'.(I don't know how to say 'muñeco' - 'snowman')

In example 3 (story 2) there has been some succesful NoM in the preceding utterances (turns 1-4), and then, the adult participant asks whether she can start describing the following picture (turn 5), i.e., implicitly asking whether the previous 
utterance (turn 3) has been fully understood by her interlocutor so that they can move on in the task. While this instance does not constitute a word-for-word sample of the types of comprehension checks pointed out by Oliver ('either tag questions, repetition with rising intonation, or questions such as 'Do you understand?'; Oliver 2002: 103), it does perform the role of a comprehension check in this specific task. In fact, researchers have already warned about the risk of overrestricting the coding of CAs to the literal examples provided in the literature, since that might lead to "inaccurate rates not reflecting the actual use of conversational adjustments displayed by participants" (Lázaro-Ibarrola \& Azpilicueta-Martínez, 2019b: 20).

As opposed to comprehension checks, acknowledgements are used by the listener to confirm to the speaker that the previous utterance has been understood properly (Hidalgo, 2019). This may be seen in example 4:

\section{Example 4 (Child-researcher)}

1. Researcher: There are two girls having fun. They're playing with a doll. The doll is in the cot. They're celebrating a birthday party.

2. Child: Ah... Number two. [Acknowledgement]

3. Researcher: The girls are jumping happily because mum has brought them a cat.

4. Child: Yes. Number four.

[Acknowledgement]

5. Researcher: The girls are now looking for the cat. They cannot seem to find it!

6. Child: Yes.

Similar to example 3, the researcher has described picture 1 (turn 1) and the child lets him know (turn 2) that he can move on to the next picture, thus intimating that he had fully understood the previous picture.

Repetitions are referred to as an interlocutor's repetition of lexical items from preceding utterances within five speaking turns (Pica \& Doughty, 1985) and they may involve repeated instances of their own production (self-repetition) or their partner's production (other repetition). It is appropriate to note that whenever a form of repetition overlapped with any other CA in the present study, they were only coded as a CA, since, as Oliver (1998) warns, including them in both categories would lead to a distortion of the total number of strategies. This may be clearly noted in the following extract from example 2 above. 
Extract from example 2 (Adult-researcher)

8. Researcher: The man is sitting holding a banana.

9. Student A: A banana?

[Confirmation check]

10. Researcher: Yes.

11. Student A: Banana?

[Confirmation check]

12. Researcher: Yeah....

Student A: Banana... The bank. [Other-repetition: partial] [Confirmation check]

All the strategies above were classified according to the communicative functions they performed. Thus, NoM strategies were classified according to whether they were used to a) repair a communication problem, including clarification requests and confirmation checks, b) confirm communication, which comprises acknowledgements and other repetitions, and c) prevent breakdowns in communication, which includes comprehension checks and self-repetitions. It is worth noting that while the two first functions (repairing and confirming communication) are listener-generated, the last one (preventing communication breakdowns) is the only function carried out by the speaker.

The analysis of each strategy was carried out considering the total number of strategies the participants used divided by the total number of utterances. One of the researchers coded all the transcriptions and the other researcher coded $20 \%$ of the whole dataset independently. Inter-rater reliability reached $95 \%$. The remaining discrepancies were solved individually on a case-by-case basis.

All values were entered into SPSS (version 24) and a normality test was run, which yielded a non-normal distribution. Therefore, the nonparametric Mann-Whitney U-test was used in all statistical analyses in this study. Significance level was fixed at $p$ $=0.05$.

\section{Results and discussion}

The first part of this section presents the results of the comparison of NoM strategies and the functions they serve in level-matched EFL children and adults performing the same oral task with an expert (research question 1), while the second part compares findings in the present study with previous research on the subject (research question 2). 
Results comprising values, percentages and statistical findings for NoM strategies in both age groups are presented in Tables 1 through 3. Table 1 displays the results for CAs and acknowledgements. Adult-expert dyads generated significantly higher NoM rates than child-expert interaction $\left(u=24.500, p=<.001^{\mathrm{b}}\right)$, indicating a significant effect for the age variable, corroborating findings in Oliver (1998) and Long (1983a), which revealed that, whenever there is a NNS adult present in the dyad, NoM rates are boosted:

Table 1. Child-expert vs. adult-expert: Conversational adjustments and acknowledgements

\begin{tabular}{cc}
\hline Child- expert & Adult-expert \\
\hline Average time: & Average time: \\
3 mins 34 secs & 5 mins 55 secs \\
\hline Average & Average \\
number of & number of \\
utterances: & utterances: \\
19.78 & 41.43 \\
(Total 791) & (Total 1160)
\end{tabular}

\begin{tabular}{|c|c|c|c|c|c|c|}
\hline & & \multirow{2}{*}{\multicolumn{2}{|c|}{ Raw }} & \multirow[b]{2}{*}{ Statistics } \\
\hline & & Raw & $\%$ & & & \\
\hline \multirow{4}{*}{ 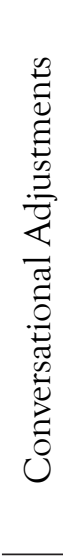 } & $\begin{array}{l}\text { Clarification } \\
\text { Requests }\end{array}$ & 17 & $2.15 \%$ & 61 & $5.26 \%$ & $\begin{array}{c}\left(u=25.500 . p<.001^{\mathrm{b}}\right) \\
(\text { sig. higher in adult } \\
\text { interaction) }\end{array}$ \\
\hline & $\begin{array}{l}\text { Confirmation } \\
\text { Checks }\end{array}$ & 3 & $0.38 \%$ & 40 & $3.45 \%$ & $\begin{array}{c}\left(u=39.000 . p<.001^{\mathrm{b}}\right) \\
\text { (sig. higher in adult } \\
\text { interaction) }\end{array}$ \\
\hline & $\begin{array}{l}\text { Comprehension } \\
\text { Checks }\end{array}$ & 0 & $0 \%$ & 1 & $0.09 \%$ & $\begin{array}{c}\left(u=130.000 \cdot p=0.743^{b}\right) \\
\quad(\text { non-significant })\end{array}$ \\
\hline & Total & 20 & $2.53 \%$ & 102 & $8.79 \%$ & $\begin{array}{c}\left(u=16.500 . p=<.001^{b}\right) \\
(\text { sig. higher in adult } \\
\text { interaction })\end{array}$ \\
\hline & knowledgements & 47 & $5.94 \%$ & 72 & $6.21 \%$ & $\begin{array}{c}\left(u=16.500 . p=<.001^{\mathrm{b}}\right) \\
(\text { sig. higher in adult } \\
\text { interaction })\end{array}$ \\
\hline & $\begin{array}{l}\text { tal number of } \\
\text { ategies }\end{array}$ & 67 & $8.47 \%$ & 174 & $15 \%$ & $\begin{array}{c}\left(u=24.500 . p<.001^{\mathrm{b}}\right) \\
(\text { sig. higher in adult } \\
\text { interaction) }\end{array}$ \\
\hline
\end{tabular}


It may be noted at this point that the higher NoM values present in the adult-expert interactions are associated with a substantially larger amount of language produced, since the older learners produced an average of 41.43 utterances per participant, whereas children produced less than half as many: 19.78. This phenomenon was also reflected in the amount of time spent performing the task (five minutes and 55 seconds for the adults, in contrast to three minutes and 34 seconds for the chidren).

Equally interesting, both age groups displayed very similar conversational patterns, since the proportional use of each conversational adjustment between both groups was strikingly similar: both populations resorted primarily to acknowledgements, followed by clarification requests, confirmation checks, and, lastly, comprehension checks. Examining each strategy in isolation, it may be noted that adults more than doubled the percentage of clarification requests with respect to children, yielding statistically significant differences $\left(u=25.500, p<.001^{\mathrm{b}}\right)$. In the case of confirmation checks, the gap increased nearly tenfold, and differences were significant $(u=39.000$, $p<.001^{\mathrm{b}}$ ). Values for comprehension checks were nearly inexistent (indeed so in the case of children), and differences between both groups non significant $(u=130.000$, $\left.p=0.743^{b}\right)$. While the scarcity of comprehension checks in children populations has already been accounted for in the literature due to the egocentricity inherent to children (e.g., Azkarai \& García Mayo, 2016: 10; Oliver, 1998: 377), the extremely low rate in the adult group might be related to their assuming that their more proficient interlocutor would understand them at all times.

Acknowledgements, as mentioned above, constituted the single most frequently used conversational adjustment by both populations, yet adult-expert interaction displayed a significantly higher number of instances of this strategy than childrenexpert interaction $\left(u=77.500, p=0.027^{b}\right)$.

Table 2 shows the values, percentages and results of statistical analyses for repetitions. Overall, the adult group produced significantly more instances of repetitions than the children in the study $\left(u=1.000, p<.001^{\mathrm{b}}\right)$. This is further borne out by differences in both self-repetition $\left(u=39.500, p<.001^{\mathrm{b}}\right)$ and other-repetition $(u=$ $5.000, p<.001^{\mathrm{b}}$ ). Once more, however, both groups feature a similar proportional use of each of these elements, with a strong preference for other-repetition $(19.83 \%$ and $11.76 \%$ for adults and children respectively) over self-repetition (12.67\% and 5.94\%). 
Table 2. Child-expert vs. adult-expert: Repetitions

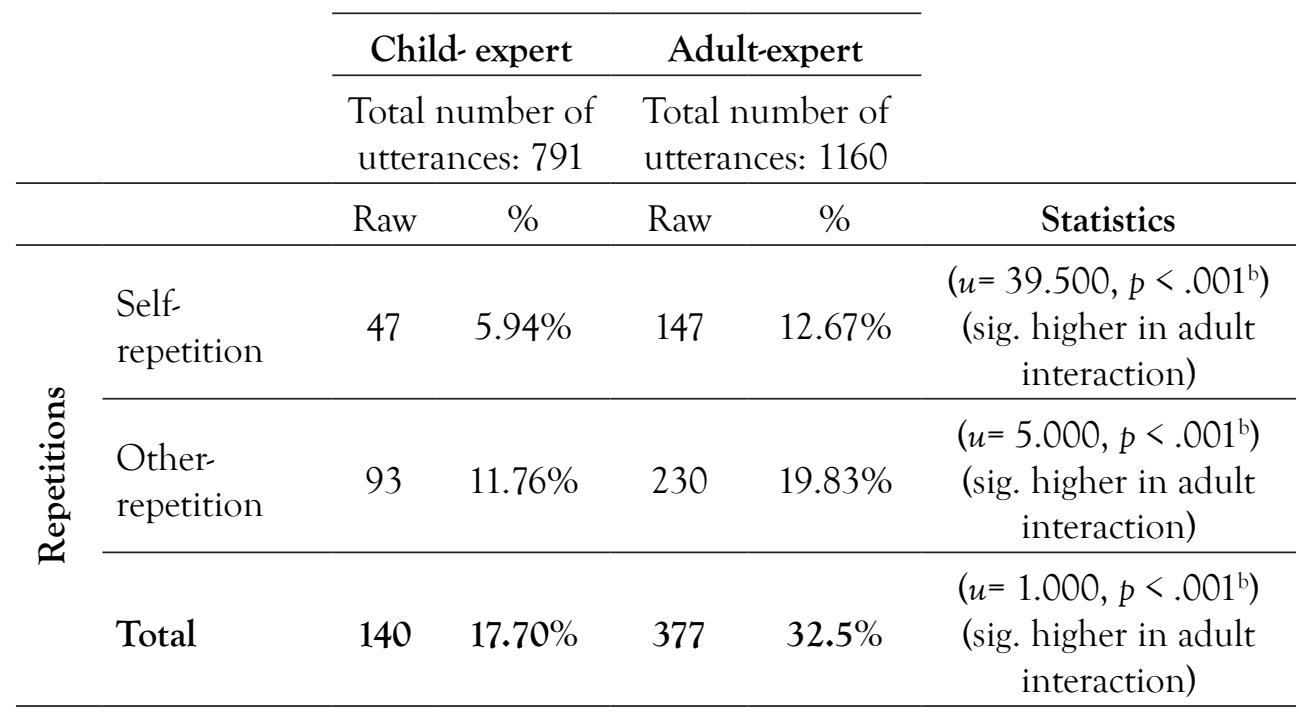

It is immediately apparent that, beyond the substantial differences in the abovementioned amount of NoM produced lies a common denominator: children-expert interactions resemble a scaled-down replica of the adult-expert conversational patterns, which might be explained by their common proficiency level. Although the adult group made a much more extensive use of the strategies, the proportional use of each of the elements analysed was very similar.

Let us now examine the communicative functions that the elements in Tables 1 and 2 serve in interaction (Table 3 ). 
Table 3. Child-expert vs. adult-expert: Communicative functions

\begin{tabular}{|c|c|c|c|c|c|}
\hline & \multicolumn{2}{|c|}{ Child-expert } & \multicolumn{2}{|c|}{ Adult-expert } & \\
\hline & \multicolumn{2}{|c|}{$\begin{array}{l}\text { Utterances: } 791 \\
\text { Total strategies } 207\end{array}$} & \multicolumn{2}{|c|}{$\begin{array}{l}\text { Utterances: } 1160 \\
\text { Total strategies } 551\end{array}$} & \\
\hline & Raw & $\%$ & Raw & $\%$ & Statistics \\
\hline $\begin{array}{l}\text { Repair (clarification } \\
\text { requests \& } \\
\text { confirmation } \\
\text { d checks) }\end{array}$ & 47 & $22.70 \%$ & 144 & $8.71 \%$ & $\begin{array}{l}(u=19.000, p< \\
\left..001^{\mathrm{b}}\right) \\
\text { (sig. higher in } \\
\text { adult interaction) }\end{array}$ \\
\hline $\begin{array}{l}\text { Confirm } \\
. \\
\text { (other-repetitions \& } \\
\text { (ocknowledgements) }\end{array}$ & 140 & $67.63 \%$ & 306 & $26.04 \%$ & $\begin{array}{l}\qquad \begin{array}{l}(u=6.500, p< \\
\left..001^{\mathrm{b}}\right)\end{array} \\
\text { (sig. higher in } \\
\text { adult interaction) }\end{array}$ \\
\hline $\begin{array}{l}\text { (self-repetitions \& } \\
\text { comprehension } \\
\text { checks) }\end{array}$ & 20 & $9.66 \%$ & 101 & $12.76 \%$ & $\begin{array}{l}\left(\begin{array}{l}u=39.000, p< \\
\left..001^{\mathrm{b}}\right)\end{array}\right. \\
(\text { sig. higher in } \\
\text { adult interaction) }\end{array}$ \\
\hline
\end{tabular}

Since each of the categories above is composed of the same elements in Tables 1 and 2, in which adults showed significantly higher rates in all but one strategy (comprehension checks), it is expected that the YLs made use of these functions to a significantly lower degree. Perhaps more importantly, the data above provide compelling evidence that adults and children used NoM in order to achieve the same communicative functions, with a clear preference for confirming communication, followed by repair, with the prevention of communication breakdowns in last place.

Research question 2 intended to compare the results in the present study with those from previous research. In order to do so, the following studies analysing NoM in children and adult populations included in the literature review have been selected (Table 4):

\section{(Children)}

1. Oliver (1998): results from ESL NNS-NS child-child interactions, since that type of dyad is closest to the type of proficiency pairing (NNS-expert) in the present study. 
2. Lázaro-Ibarrola \& Azpilicueta Martínez (2019b): results from same-level EFL NNS-NNS child-child interactions using tasks with identical layout, yet different content, to the ones in the present study.

(Adults)

1. Long (1983a): results from ESL NNS-NS adults.

2. Lázaro-Ibarrola \& Azpilicueta Martínez (2019b): results from same-level EFL NNS-NNS adult-adult interactions using tasks with identical layout, yet different content, to the ones in the present study.

Table 4. NoM in children and adult studies

\begin{tabular}{|c|c|c|c|c|c|c|c|}
\hline & \multirow{3}{*}{$\begin{array}{c}\text { Oliver } \\
(1998) \\
\text { ESL }\end{array}$} & \multirow{3}{*}{\multicolumn{2}{|c|}{$\begin{array}{cc}\text { LI-AM } & \text { Pres. } \\
(2019 b) & \text { Study } \\
\text { EFL } & \text { EFL }\end{array}$}} & \multirow{3}{*}{$\begin{array}{c}\text { Long } \\
(1983 a) \\
\text { ESL }\end{array}$} & \multirow{3}{*}{$\begin{array}{c}\text { LI-AM } \\
(2019 b) \\
\text { EFL }\end{array}$} & \multirow{3}{*}{$\begin{array}{c}\text { Pres. } \\
\text { Study } \\
\text { EFL }\end{array}$} \\
\hline & & & & & & & \\
\hline & & & & & & & \\
\hline & & \multicolumn{3}{|c|}{ CHILDREN } & \multicolumn{3}{|c|}{ ADULTS } \\
\hline & & $\begin{array}{l}\text { NNS- } \\
\text { NS }\end{array}$ & $\begin{array}{l}\text { NNS- } \\
\text { NNS }\end{array}$ & $\begin{array}{l}\text { NNS- } \\
\text { expert }\end{array}$ & NNS-NS & NNS-NNS & $\begin{array}{l}\text { NNS- } \\
\text { expert }\end{array}$ \\
\hline & & $\begin{array}{l}\text { Child- } \\
\text { child }\end{array}$ & $\begin{array}{l}\text { Child- } \\
\text { child }\end{array}$ & $\begin{array}{l}\text { Child- } \\
\text { expert }\end{array}$ & $\begin{array}{l}\text { Adult- } \\
\text { adult }\end{array}$ & $\begin{array}{l}\text { Adult- } \\
\text { adult }\end{array}$ & $\begin{array}{l}\text { Adult- } \\
\text { expert }\end{array}$ \\
\hline \multirow{5}{*}{ 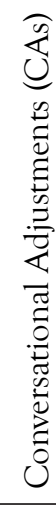 } & $\begin{array}{l}\text { Clarification } \\
\text { Requests }\end{array}$ & 3.97 & 3.69 & 2.15 & 10.35 & 1.44 & 5.26 \\
\hline & $\begin{array}{l}\text { Confirmation } \\
\text { Checks }\end{array}$ & 6.44 & 1.02 & 0.38 & 18.15 & 1.75 & 3.45 \\
\hline & $\begin{array}{l}\text { Comprehension } \\
\text { Checks }\end{array}$ & 0.41 & 1.66 & 0 & 18.15 & 1.52 & 0.09 \\
\hline & Acknowledgements & - & 8.41 & 5.94 & - & 7.06 & 6.21 \\
\hline & Total CAs & 10.82 & 14.78 & 8.47 & 46.65 & 11.77 & 15.01 \\
\hline \multicolumn{2}{|c|}{ Self-repetition } & 21.66 & 29.81 & 5.94 & 41.06 & 27.09 & 12.67 \\
\hline \multicolumn{2}{|c|}{ Other-repetition } & 22.91 & 8.54 & 11.76 & 15.09 & 12.52 & 19.83 \\
\hline \multicolumn{2}{|c|}{ Total repetition } & 44.57 & 38.35 & 17.7 & 56.15 & 39.61 & 32.5 \\
\hline \multicolumn{2}{|c|}{ Total NoM strategies } & 55.39 & 53.13 & 26.17 & 102.8 & 51.38 & 47.51 \\
\hline
\end{tabular}


First and foremost the overall similarities in the conversational patterns in the present study, which portray child-expert interactions as a scaled-down replica of adultexpert interactions, are consistent with initial findings comparing ESL NNS-NS childchild (Oliver, 1998) and NNS-NS adult-adult (Long, 1983a) interactions. These results support the notion that not only ESL, but also EFL dyads including a NNS adult interacting with a NS/expert trigger the highest amount of NoM.

However, these proportionally similar conversational patterns were not found in Lázaro-Ibarrola \& Azpilicueta Martínez (2019b), which compared EFL NNS-NNS child-child and NNS-NNS adult-adult interaction. What is more, the patterns in their study revealed significantly higher NoM rates for the YLs in the overall CAs and selfrepetitions percentages, pointing at a clear influence of the interlocutor factor on the type and amount of NoM. In fact, the child-expert combination in the current study reduces overall NoM rates to less than half if compared to the NNS-NNS child-child interaction in Lázaro-Ibarrola \& Azpilicueta Martínez (2019b), i.e., from 53.13\% to $26.17 \%$, and the same applies for CAs: from $14.78 \%$ to $8.47 \%$. In other words, YLs' NoM seems to dwindle when interaction takes place with an adult expert.

This phenomenon does not occur with the NNS-NNS adult group, and, although there is a decrease in overall NoM rates (from $51.38 \%$ in Lázaro-Ibarrola \& Azpilicueta Martinez, 2019b, to $47.51 \%$ in the present study), this is far less substantial. In fact, the tendency reverses if we focus on CAs in isolation, since the adult-expert combination experienced an increase if compared with the adult-adult interactions in LázaroIbarrola \& Azpilicueta Martínez (2019b) (from 11.77\% to 15.01\%).

These opposing results might be related to the interlocutor factor, and suggest that YLs might be more sensitive than adults to differences in the age and perceived role of their conversational partners. The children in the study may have adopted a more submissive role when interacting with an expert they may have associated with a 'teacher role', an observation already pointed out in the literature (Scarcella \& Higa, 1981), an influence to which the adults might have been more oblivious. The fact that the expert speaker in the dyad was an adult might have also had a positive impact on the NoM displayed by the adult group. Interestingly, both populations seem to have a tendency to imitate the expert's speech (note the increase in other-repetition rates) if compared to peer interaction.

Secondly, the amount of NoM in all strategies is clearly lower than either of the ESL studies compared in both populations, concurring with previous research comparing NoM in ESL and EFL populations (e.g., García Mayo \& Hidalgo, 2017; Oliver, 1998), yet seems to be past the 'red line' or minimum threshold level in Lázaro-Ibarrola \& Azpilicueta Martínez (2015). However, it is important to note at this point that data 
coding in Long's study (1983a) with NNS-NS adult learners might have been different to that in the rest of studies subject to scrutiny here. This may be noted in the fact that the value for 'Total NoM strategies' in Long's study exceeds 100\%. As mentioned in section 3.5. (Data coding and analysis), this was avoided in the rest of the studies analysed, as whenever a CA and a form of repetition overlapped, such strategy was only coded as a CA in order to avoid a misrepresentation of the percentages, following Oliver (1998).

\section{Conclusion, limitations and pedagogical implications}

The present study has investigated the NoM present in the interactions of children and adults with a proficient speaker of the TL. The first research question intended to compare the interactional patterns of these two populations. An analysis of the NoM strategies and functions displayed by the participants has revealed that the adult group were able to negotiate significantly more than children in all NoM strategies, with the exception of comprehension checks, although these were also higher in the adult group. These results underpin the notion that, when comparing low level EFL learners interacting with an adult expert, older students are at an advantage in terms of their outright production of NoM if compared with YLs, who might appear to take on a more submissive role. As the language level was similar in both populations the main reason for this difference seems to be the young age of the learners, who are not mature enough to play a leading role in most activities and, linguistically speaking, cannot use NoM strategies as much as adults do. More research would be needed in order to ascertain whether a child expert partner would yield different results with these two EFL age groups. Likewise, it would be interesting to know if similar findings could be revealed when students negotiate in their own L1s.

Results have also exposed strikingly similar conversational patterns in the proportional use of NoM strategies between both age groups, i.e., children use the same types of strategies, and for the same purposes as adults. This finding might be explained by the proficiency level exerting a homogeneising effect on the types and functions of NoM present in beginner EFL learners' interactions with an expert.

The second research question intended to examine how the results in the present study compared to the existing research. Firstly, results have corroborated previous findings on ESL child and adult learners, and indicate that dyads including an expert and a NNs adult trigger the highest NoM rates of all proficiency and age combinations. Secondly, the age-NoM relation of EFL NNS-expert interactions is similar to that in ESL NNS-NS interactions from previous research. In other words, children produce the same types of NoM strategies as adults to a lesser, yet proportional, extent. 
However, if we compare the learner-expert combination in the present study with EFL peer-peer interaction in existing research using the same task, with age and level-matched pairs, we are faced with opposing interactional patterns. Children in peer interaction negotiate for meaning significantly more than adults in that form of interaction, and significantly more than children interacting with an expert, a common form of interaction (student-teacher) in EFL classes worlwide. Peer-peer interactions see children's NoM rates increase in all strategies (CAs and repetitions), with the exception of other-repetition. This exception could be explained by their perception of their conversational partner as an 'expert' leading to them trying to imitate their speech, at the same time they might take on a more submissive role, thus triggering fewer instances of NoM.

All in all, this study questions the notion of a clear-cut inversely proportional relation between proficiency in the TL and amount of NoM with EFL learners, and suggests it is more complex and dynamic, one in which NoM is mediated by age, type of learning (ESL vs EFL) and interlocutor status, notwithstanding other variables out of the scope of the present study, such as task typology. Much more research is needed in order to ascertain the type of influence each of these elements exert on each population.

The present study contains several methodological limitations that should be addressed in further research. First, the tasks we used were novel and had not been extensively used in previous research. Also, the fact that the researcher specifically pointed out which picture(s) were misplaced when both posters did not match constitutes a limitation, because, on occasions, the participants would then simply swap the position of two pictures without negotiating for meaning any further. If the researcher had simply let them know that one (or several) picture(s) were misplaced, this might have forced participants to double-check the whole story following a (probably) more meticulous approach, and, possibly, negotiating for meaning more. This was done for time constraints primarily. On the other hand, the story itself could have been more suitable for one of our populations, for instance, perhaps the adults found it too simple, which could, in turn, have affected their interaction.

Findings in the study point towards the pedagogical implication of implementing in-class peer-peer interaction activities as a regular classrooom practice with low-level EFL YLs, as opposed to more traditional student-teacher interactions, since that age group seems to benefit from more opportunities for NoM in that type of pairing than adults, who appear to negotiate for meaning more when interacting with a proficient speaker of the TL. However, the results also highlight the potential of learner-expert combinations as a valuable means to promote the activation of specific structures and lexicon in the learners' production via other-repetitions, since the low proficiency 
learners (including YLs) in the study tended to imitate more of their partners' speech as a perceived expert speaker of the TL. Consequently, different dyad combinations would appear to yield different learning potentialities (i.e., imitation of particular structures/lexicon versus promoting negotiation of meaning). Finally, the study ultimately encourages language practitioners to become good models of language use, that is, to achieve high levels of proficiency in the language they teach, since both children and adults seemed to imitate their conversational partner's speech when they perceived him/her as an 'expert', a phenomenon which might be frequent in learnerteacher interactions worldwide.

\section{Acknowledgements}

The present study paper was funded by the Ministerio de Economía y Competitividad (Funder ID: http://dx.doi.org/10.13039/501100003329, Grant Number: FFI2012-32212). We gratefully acknowledge the assistance of the staff at CPEIP Lorenzo Goicoa, UNED Pamplona-Iruña and EOIDNA, in particular to Juana $\mathrm{M}^{\mathrm{a}}$ Urbiola and Olga Zamanillo. Finally, we are also thankful to Israel Azpilicueta for letting us use his drawings for the tasks in this study.

\section{References}

Alegría de la Colina, A., \& García Mayo, M.P. (2009). Oral interaction in taskbased EFL learning: The use of the L1 as a cognitive tool. International Review of Applied Linguistics in Language Teaching, 47(3-4), 325-345.

Azkarai, A., \& García Mayo, M.P. (2015). Task-modality and L1 use in EFL oral interaction. Language Teaching Research, 19(5), 550-571.

Azkarai, A., \& Imaz Agirre, A. (2016). Negotiation of meaning strategies in child EFL mainstream and CLIL settings. Tesol Quarterly, 50(4), 844-870.

Azkarai, A., \& Oliver, R. (2019). Negative feedback on task repetition: ESL vs. EFL child settings. The Language Learning Journal, 47(3), 269-280.

Azpilicueta-Martínez, R. (2020). Verbal evidence of task-related strategies in EFL: Children and adult interactions. International Journal of English Studies, 20(3), 1-28.

Birdsong, D. (2005). Interpreting age effects in second language acquisition. In J. F. Kroll \& A. M. B. DeGroot (Eds.), Handbook of Bilingualism: Psycholinguistic perspectives (pp. 109-127). New York: Oxford University Press.

Butler, Y. G., \& W. Zeng. (2014). Young foreign language learners' interactions during task-based paired assessment. Language Assessment Quarterly, 11(1), 45-75. 
Dalton-Puffer, C. (2011). Content-and-language integrated learning: From practice to principles? Annual Review of Applied Linguistics, 31, 182-204.

Ellis, R. (1985). Teacher-pupil interaction in second language development. In S. M. Gass, \& C. G. Madden (Eds.), Input in Second Language Acquisition (pp. 69-85). Rowley, MA: Newbury House.

García Mayo, M.P., (2018). Child task-based interaction in EFL settings: Research and challenges. International Journal of English Studies, 18(2), 119-143.

García Mayo, M.P., \& García Lecumberri, M.L. (2003). Age and the Acquisition of English as a Foreign Language. Clevedon: Multilingual Matters.

García Mayo, M.P., \& Lázaro-Ibarrola, A. (2015). Do children negotiate for meaning in task-based interaction? Evidence from CLIL and EFL settings. System, 54, 40-54.

García Mayo, M.P., \& Hidalgo, M. (2017). L1 use among young EFL mainstream and CLIL learners in task-supported interaction. System, 67, 132-145.

García Mayo, M.P., \& Imaz Agirre, A. (2019). Task modality and pair formation method: Their impact on patterns of interaction and LREs among EFL primary school children. System, 80, 165-175.

Gass, S. M., \& Varonis, E. M. (1985). Task variation and nonnative/nonnative negotiation of meaning. In S. M. Gass, \& C. G. Madden (Eds.), Input in Second Language Acquisition (pp. 149-161). Rowley, MA: Newbury House.

Kazemi, S. A., \& Zarei, L. (2015). The efficacy of topic familiarity on oral presentation: Extensive speaking assessment task of Iranian EFL learners in TBLT. International Journal of Applied Linguistics and English Literature, 4(3), 93-97.

Lázaro-Ibarrola, A., \& Azpilicueta-Martínez, R. (2015). Investigating negotiation of meaning in EFL children with very low levels of proficiency. International Journal of English Studies, 15(1), 1-21.

Lázaro-Ibarrola, A., \& Azpilicueta-Martínez (2019a). Spotting the differences between child-child and child-adult interactions: Evidence from Spanish EFL learners at low levels of proficiency. In J. Rokita-Jaśkow and M. Ellis (Eds.), Early Instructed Second Language Acquisition: Pathways to Competence (pp. 80-106). Clevedon: Multilingual Matters.

Lázaro-Ibarrola, A., \& Azpilicueta-Martinez, R. (2019b). Negotiation of meaning in child-child vs. adult-adult interactions: Evidence from low proficiency EFL learners. International Review of Applied Linguistics in Language Teaching, (ahead-of-print).

Long, M. (1996). The role of the linguistic environment in second language acquisition. In W. Ritchie \& T. Bhatia (Eds.), Handbook of Second Language Acquisition (pp. 413-468). San Diego: Academic Press. 
Long, M. H., \& Porter, P. A. (1985). Group work, interlanguage talk and second language acquisition. TESOL Quarterly, 19(2), 207-227.

Mackey, A. (1999). Input, interaction, and second language development: An empirical study of question formation in ESL. Studies in Second Language Acquisition, 21(4), 557-587.

Mackey, A., \& Oliver, R. (2002). Interactional feedback and children's L2 development. System, 30(4), 459-477.

Mackey, A., Oliver, R., \& Leeman, J. (2003). Interactional input and the incorporation of feedback: An exploration of NS-NNS and NNS-NNS adult and child dyads. Language Learning, 53(1), 35-66.

Mackey, A., \& Gass, S. (2005). Second Language Research. Methodology and Design. Mahwah: Erlbaum.

Muñoz, C., \& Singleton, D. (2011). A critical review of age-related research on L2 ultimate attainment. Language Teaching, 44(1), 1-35.

Oliver, R. (1998). Negotiation of meaning in child interactions. The Modern Language Journal, 82(3), 372-386.

Oliver, R. (2000). Age differences in negotiation and feedback in classroom and pairwork. Language Learning, 50(1), 119-151.

Oliver, R. (2002). The patterns of negotiation for meaning in child interactions. The Modern Language Journal, 86(1), 97-111.

Oliver, R. (2009). How young is too young? Investigating negotiation of meaning and feedback in children aged five to seven years. In A. Mackey \& C. Polio (Eds.), Multiple Perspectives on Interaction. Second Language Research in Honor of Susan M. Gass (pp. 135-156). New York: Routledge.

Oliver, R., \& Mackey, A. (2003). Interactional context and feedback in child ESL classrooms. The Modern Language Journal, 87(4), 519-533.

Paradis, J. (2007). Second language acquisition in childhood. In E. Hoff, \& M. Shatz (Eds.) Blackwell Handbook of Language Development (pp. 387-406). Malden MA: Blackwell.

Philp, J., \& Tognini, R. (2009). Language acquisition in foreign language contexts and the differential benefits of interaction. International Review of Applied Linguistics, $47,245-266$.

Pienemann, M., \& Johnston, M. (1987). A Predictive Framework of SLA. Unpublished manuscript. University of Sydney and AMES NSW, Australia. 
Pinter, A. (2006). Verbal evidence of task related strategies: Child versus adult interactions. System, 34(4), 615-630.

Pinter, A. (2007). Some benefits of peer-peer interaction: 10 year-old children practicing with a communicative task. Language Teaching Research, 11(2), 189-207.

Qiu, X. (2020). Functions of oral monologic tasks: Effects of topic familiarity on L2 speaking performance. Language Teaching Research, 24(6), 745-764.

Scarcella, R.C., \& Higa, C. (1981). Input, negotiation, and age differences in second language acquisition 1. Language Learning, 31(2), 409-434.

Shehadeh, A. (1999). Non-native speakers' production of modified comprehensible output and second language learning. Language Learning, 49(4), 627-675.

Singleton, D., \& Ryan, L. (Eds.). (2004). Language Acquisition: The Age Factor. Clevedon: Multilingual Matters.

Sylvén, L. K. (2013). CLIL in Sweden-why does it not work? A metaperspective on CLIL across contexts in Europe. International Journal of Bilingual Education and Bilingualism, 16(3), 301-320.

Thompson, R.A., \& Jackson, S. (1998). Ethical dimensions of child memory research. Applied cognitive psychology: The Official Journal of the Society for Applied Research in Memory and Cognition, 12(3), 218-224.

Tuan, L. T., \& Nhu, N. T. K. (2010). Theoretical review on oral interaction in EFL classrooms. Studies in Literature and Language, 1(4), 29-48.

Van den Branden, K. (1997). Effects of negotiation on language learners' output. Language Learning, 47(4), 589-636.

Varonis, E. M., \& Gass, S. (1985). Non-native/non-native conversations: A model for negotiation of meaning. Applied Linguistics, 6(1), 71-90. 


\section{Appendices}

Appendix A - Story 1: The Birthday Party
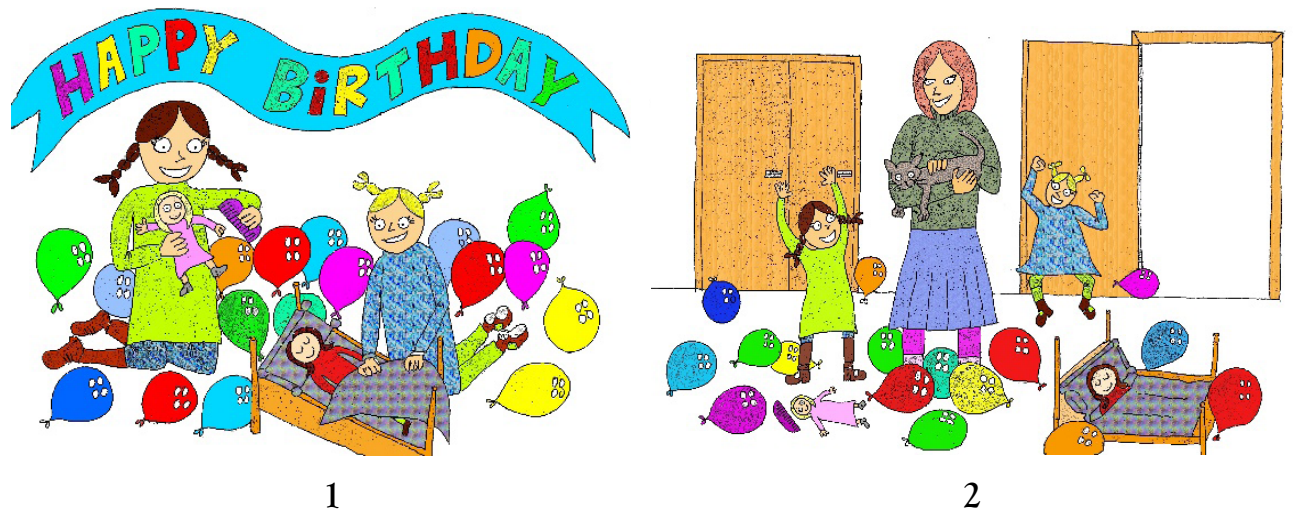

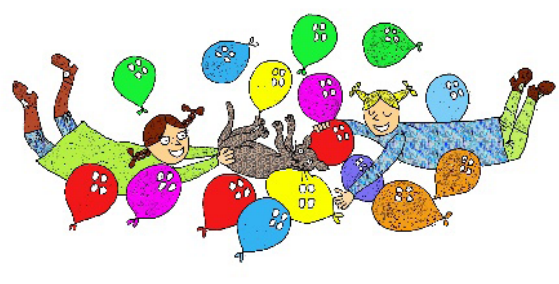

3

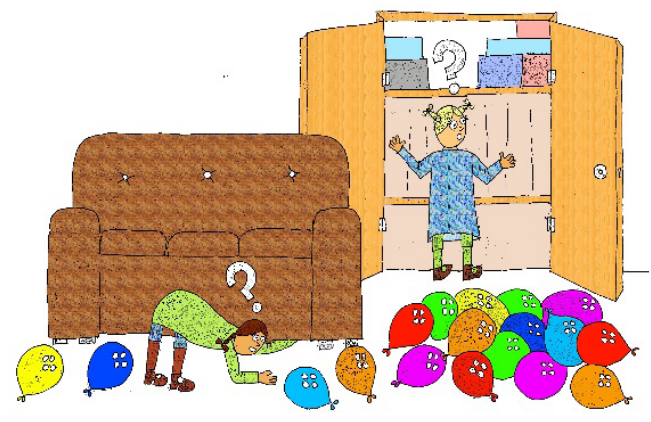

4

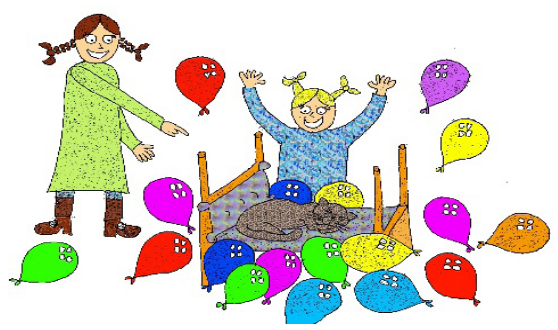

5 
Distractors (story 1)
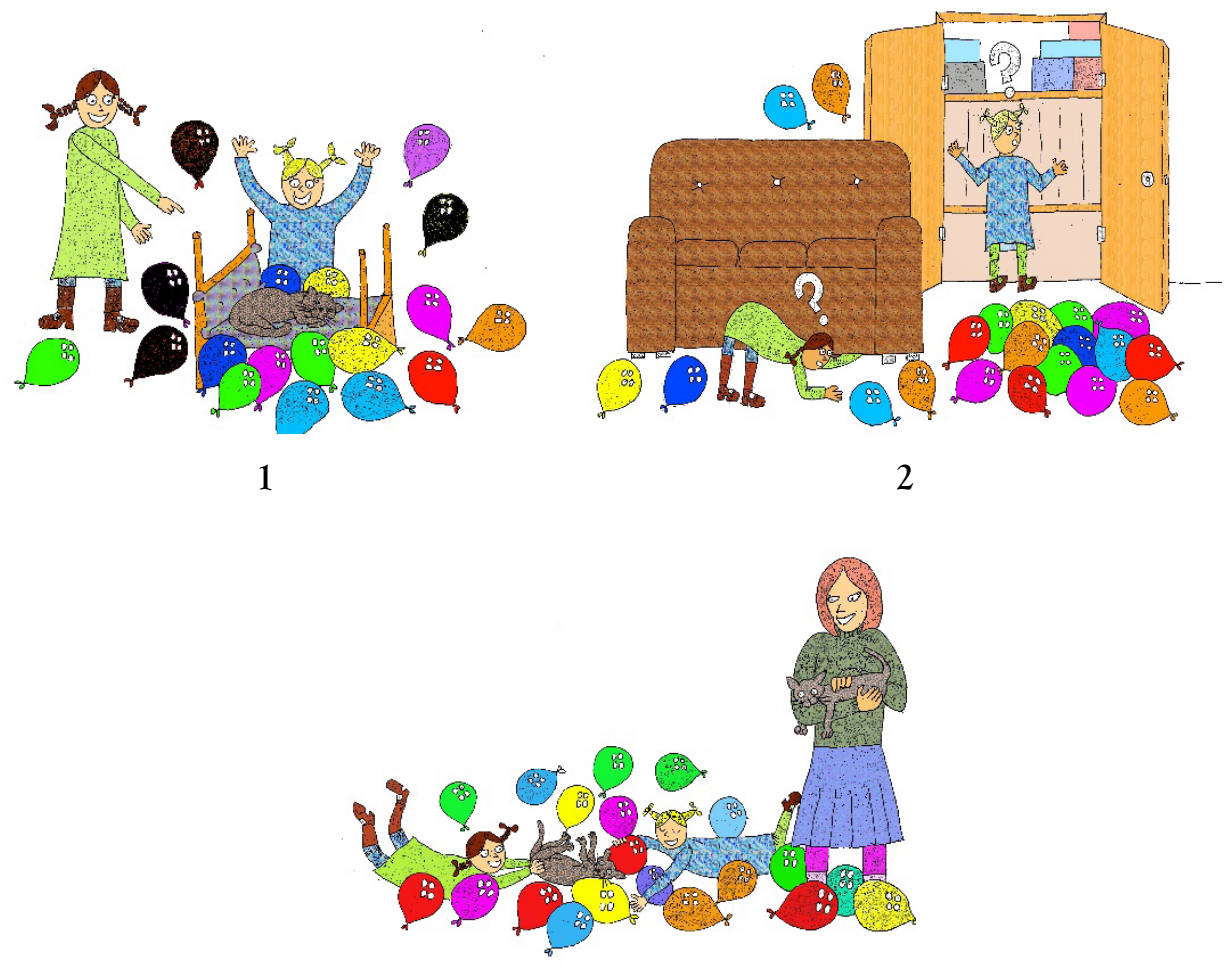

3 
Appendix B - Story 2: The Snowman

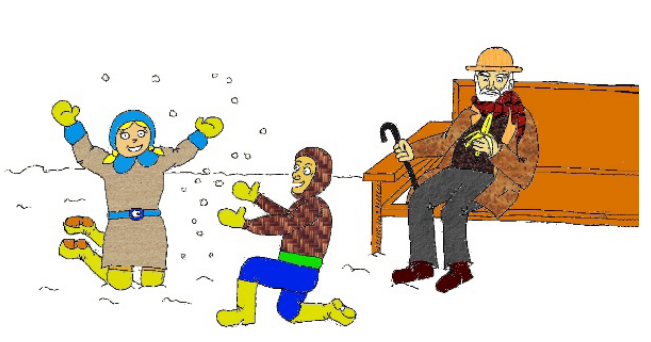

1

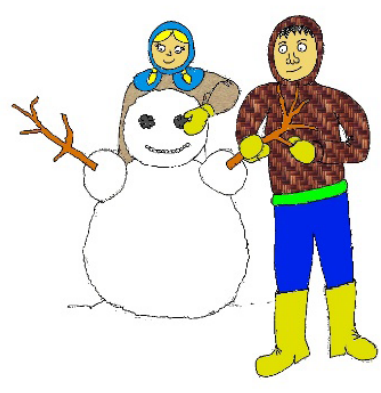

3

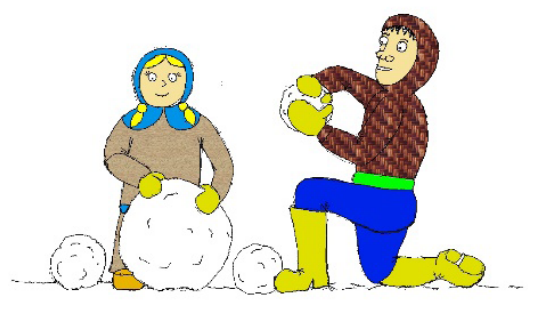

2

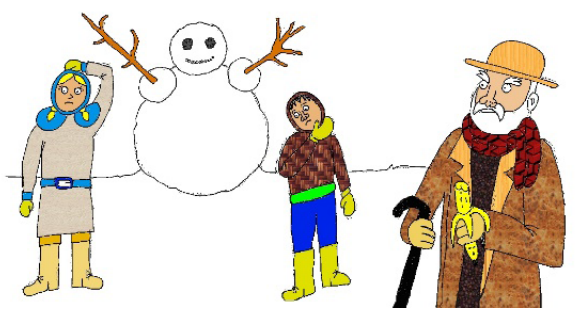

4

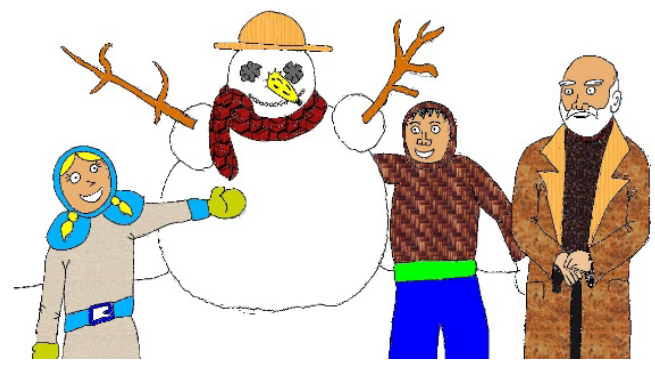

5 
Distractors (story 2)

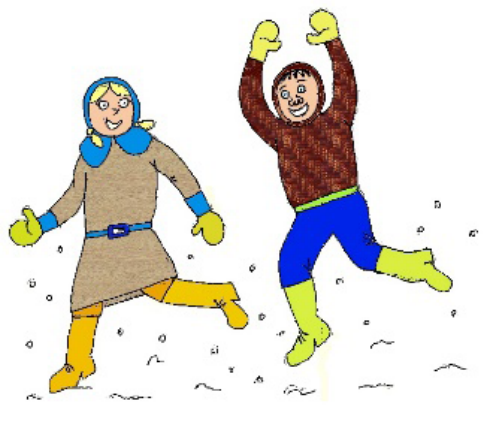

1

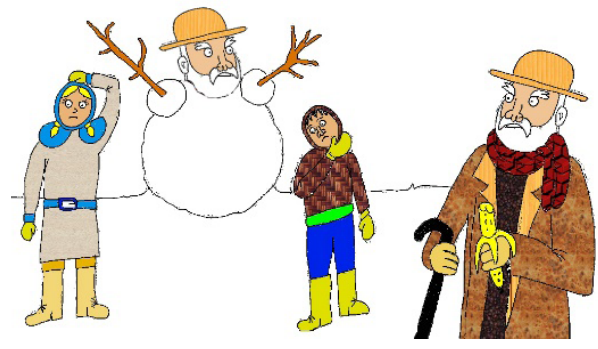

2

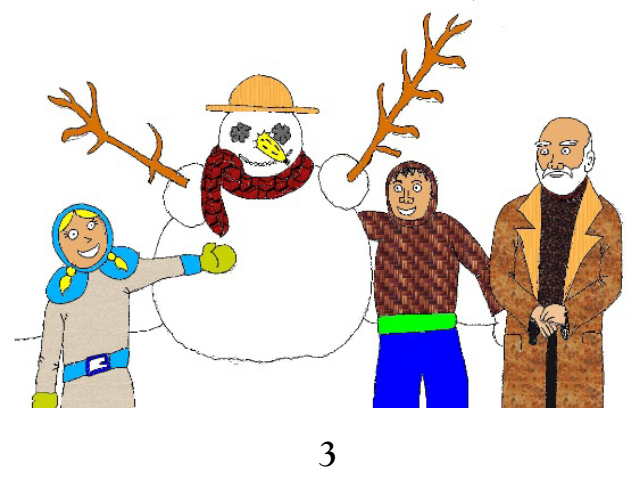


Appendix C - Script.

\section{Warm-up, ice-breaking conversation}

\begin{tabular}{|c|c|c|}
\hline Input for adults & Backup language & Feedback \\
\hline $\begin{array}{l}\text { Hello/good morning/ } \\
\text { good afternoon/evening }\end{array}$ & & \multirow{4}{*}{$\begin{array}{l}\text { Ok/Well done/ } \\
\text { Alright/Great/ } \\
\text { Excellent }\end{array}$} \\
\hline How are you/doing? & $\begin{array}{l}\text { Are you ok? Are you alright? } \\
\text { (thumbs up sign) }\end{array}$ & \\
\hline What's/are your name (s)? & $\begin{array}{l}\text { My name is.... You are....? } \\
\text { (pointing at self) }\end{array}$ & \\
\hline Where are you from? & Do you live in Pamplona? & \\
\hline Input for children & Backup language & Feedback \\
\hline $\begin{array}{l}\text { Hello/good morning/ } \\
\text { good afternoon / evening }\end{array}$ & & \multirow[t]{7}{*}{$\begin{array}{l}\text { Ok/Well done/Alright/ } \\
\text { Great/Excellent }\end{array}$} \\
\hline How are you/doing? & $\begin{array}{l}\text { Are you ok? Are you alright? } \\
\text { (thumbs up sign) }\end{array}$ & \\
\hline What's your name? & $\begin{array}{l}\text { Are you (saying subject's } \\
\text { name)...? }\end{array}$ & \\
\hline How old are you? & Are you 7,8 or $9 ?$ & \\
\hline Where do you live? & $\begin{array}{l}\text { Do you live in Pamplona/ } \\
\text { Navarra...? }\end{array}$ & \\
\hline $\begin{array}{l}\text { Have you got any brothers } \\
\text { or sisters? }\end{array}$ & $\begin{array}{l}\text { Have you got one brother/ } \\
\text { sister? }\end{array}$ & \\
\hline $\begin{array}{l}\text { What is your favourite } \\
\text { sport/hobby? }\end{array}$ & Do you like football/tennis? & \\
\hline
\end{tabular}

\section{Script for the stories}

Now then (Subject A's name), here's a story in pictures. (Subject A's name), the story is mixed up, it's not in order. I'm going to tell you the story. You must listen to me and put the story in order next to these numbers - 1, 2, 3, 4, 5. Do you understand what you have to do?

Let's do an example. I have the story and you put these pictures in order next to the numbers. 
Researcher: Picture 1: There are two girls having fun. They're playing with a doll. The doll is in the cot. They're celebrating a birthday party.

Researcher: Picture 2: The girls are jumping happily because mum has brought them a cat.

Researcher: Picture 3: The children are playing with the cat on the floor. The place is full of balloons!

Researcher: Picture 4: The girls are now looking for the cat. They cannot seem to find it!

Researcher: Picture 5: Oh look at it! It was sleeping on the cot all the time! 
2.- It's your turn now. Now then (Subject A's name), here's a story in pictures. I have the same story but the story is mixed up, it's not in order. (Subject A's name): you have to tell me the story but you must not show me the pictures.

\section{STORY 2}

\begin{tabular}{|c|c|c|c|c|c|}
\hline $\begin{array}{l}\text { Picture } 1 \\
\text { - Girl and } \\
\text { boy playing } \\
\text { in the snow } \\
\text { in the park. } \\
\text { - Old man } \\
\text { on bench in } \\
\text { background } \\
\text { with hat, } \\
\text { scarf, eating } \\
\text { a banana. }\end{array}$ & $\begin{array}{l}\text { Picture } 2 \\
\text { - They start } \\
\text { to make a } \\
\text { snowman, } \\
\text { rolling big } \\
\text { and small } \\
\text { snowballs. }\end{array}$ & $\begin{array}{l}\text { Picture } 3 \\
\text { - Body, head } \\
\text { and mouth } \\
\text { made } \\
\text { - girl putting } \\
\text { on stones for } \\
\text { eyes } \\
\text { - Boy putting } \\
\text { in sticks for } \\
\text { arms. }\end{array}$ & $\begin{array}{l}\text { Picture } 4 \\
\text { - Snowman } \\
\text { nearly } \\
\text { finished but } \\
\text { missing nose, } \\
\text { hat, scarf. } \\
\text { - Children } \\
\text { wondering. } \\
\text { - Old man } \\
\text { looking at } \\
\text { snowman. }\end{array}$ & $\begin{array}{l}\text { Picture } 5 \\
\text { - Smiling } \\
\text { old man } \\
\text { and happy } \\
\text { subjects } \\
\text { looking at } \\
\text { snowman. } \\
\text { - Snowman } \\
\text { wearing hat } \\
\text { and scarf } \\
\text { from old } \\
\text { man, plus } \\
\text { banana for } \\
\text { nose. }\end{array}$ & \\
\hline \multicolumn{5}{|c|}{ Backup questions } & $\begin{array}{l}\text { Feedback } \\
\text { (choose } \\
\text { from) }\end{array}$ \\
\hline $\begin{array}{l}\text { Picture } 1 \\
\text { How many } \\
\text { subjects are } \\
\text { there? } \\
\text { Are they boys } \\
\text { or girls? } \\
\text { What are they } \\
\text { doing? } \\
\text { Are they } \\
\text { running? } \\
\text { What's the } \\
\text { weather like? } \\
\text { Is it snowy? } \\
\text { What is the } \\
\text { old man doing? } \\
\text { Is he eating a } \\
\text { banana? }\end{array}$ & $\begin{array}{l}\text { Picture } 2 \\
\text { What are the } \\
\text { subjects doing? } \\
\text { Are they } \\
\text { making } \\
\text { snowballs? } \\
\text { Are the } \\
\text { snowballs } \\
\text { different? } \\
\text { What is } \\
\text { different? } \\
\text { Is this a big } \\
\text { snowball and } \\
\text { this a small } \\
\text { snowball? }\end{array}$ & $\begin{array}{l}\text { Picture } 3 \\
\text { What parts of } \\
\text { the snowman } \\
\text { are finished? } \\
\text { Does the } \\
\text { snowman have } \\
\text { a body/head/ } \\
\text { mouth? } \\
\text { What is the } \\
\text { girl doing? } \\
\text { Is she putting } \\
\text { on the eyes? } \\
\text { What is the } \\
\text { boy doing? } \\
\text { Is he putting } \\
\text { on the arms? }\end{array}$ & $\begin{array}{l}\text { Picture } 4 \\
\text { Is the } \\
\text { snowman } \\
\text { finished? } \\
\text { What is } \\
\text { missing? } \\
\text { Does the } \\
\text { snowman have } \\
\text { a nose? } \\
\text { What are the } \\
\text { subjects doing? } \\
\text { Are they } \\
\text { looking for a } \\
\text { nose? } \\
\text { What is the } \\
\text { old man doing? } \\
\text { Is he looking } \\
\text { at the } \\
\text { snowman? }\end{array}$ & $\begin{array}{l}\text { Picture } 5 \\
\text { What are the } \\
\text { subjects doing? } \\
\text { Are they } \\
\text { happy? } \\
\text { Why are they } \\
\text { happy? } \\
\text { Is the } \\
\text { snowman } \\
\text { finished now? } \\
\text { What did they } \\
\text { use for a nose? } \\
\text { What else } \\
\text { is on the } \\
\text { snowman? } \\
\text { Is the } \\
\text { snowman } \\
\text { wearing a hat } \\
\text { and a scarf? }\end{array}$ & $\begin{array}{l}\text { Well done/ } \\
\text { That's right/ } \\
\text { Ok/Brilliant/ } \\
\text { Excellent/ } \\
\text { Good }\end{array}$ \\
\hline
\end{tabular}


